\title{
THE GROWTH OF OIL PALM VARIETIES (ELAEIS GUINEENSIS JACQ.) ON SUBSOIL MEDIA TREATED WITHSEVERAL DOSAGES OF NITROGEN FERTILIZER
}

\author{
Siti Khairani ${ }^{1 *}$, Erwin Nyak Akoeb², Edy Sigit Sutarta ${ }^{3}$, T. Sabrina ${ }^{4}$ \\ ${ }^{1}$ Post Graduate of Agrotechnology, University of North Sumatra, Medan, Indonesia \\ ${ }^{2}$ Palm Oil Research Center, University of North Sumatra, Medan, Indonesia \\ ${ }^{3}$ Agrotechnology Department, University of North Sumatra, Medan, Indonesia \\ ${ }^{4}$ Agriculture Faculty, University of North Sumatra, Medan, Indonesia \\ *Corresponding Author: khairani.sk@gmail.com
}

\begin{abstract}
Oilpalmis one of important export commodities performing as the country's main foreign exchange from the trade of crops. Nitrogen is a limiting factor of plant growth. This study aims to determine: 1) the appropriate dose of absorption of nitrogen and growth in some high yielding varieties of oil palm; 2) the superior varieties of oil palm crops that provide no effect from the nitrogen nutrients and; 3) the interaction between varieties and nitrogen fertilizer on nitrogen nutrient absorption efficiency. This research was conducted in Palm Oil Research Centre at the District of Deli Serdang, the Province of North Sumatra.The research used Factorial Random Block Design with 2 factors. The first factor is varieties (Avros 540, PPKS 239, Simalungun, Langkat and 718PPKS). The second factor is $N$ fertilizer which consists of without $N$ fertilizer, $25 \%$ fertilizer recommendation, $50 \%$ fertilizer recommendation, $75 \%$ fertilizer recommendation and $100 \%$ fertilizer recommendation. The results showed that the varieties of oil palm used have different characteristics on plant height, stem diameter and number of leaves. The Simalungun variety was the best variety and its combination with $100 \%$ recommendation $N$ was the best result in increasing plant heightof oil palm. Meanwhile the combination with $50 \%$ recommendation $N$ was the best result in increasing stem diameter and number of leavesof oil palm.
\end{abstract}

Keywords: oilpalm, nitrogen fertilizer, variety

\section{INTRODUCTION}

Oil palm plays an important role in increasing the country's foreign exchange in Indonesia, where Indonesia is the world's major palm oil producer. In addition, oil palm plantations play a role in the absorption of labor and the improvement of the economy in Indonesia. The area of oil palm cultivation in Indonesia is also increasing from year to year reaching 11.3 million ha in 2015 consisting of large plantations and smallholders (Deptan, 2015).

Development of commercial oil palm plantations should be able to provide high production assurance and optimal benefits for the company. Planted materials should be of high quality and can be guaranteed (legitimized) by seed producers.

Selection of improper planting materials will carry a very big risk. The company will suffer losses of funds, time and effort if the seeds are not in accordance with the expected results. This can only be known after the plant begins to produce, 2 - 4 years later (Lubis, 2003).

Nitrogen is the most important element of macro nutrients. $\mathrm{N}$ plant needs will be higher than other nutrients, and $\mathrm{N}$ is a limiting factor of crop productivity. Lack of $\mathrm{N}$ will cause plants not to grow optimally, while the excess $\mathrm{N}$ besides inhibiting plant growth will also cause environmental pollution (Duan et al., 2007). Nitrogen (N) is also a major constituent of cell protoplasm, acamino, protein, amide, alkaloids, and chlorophyll. Lack of nitrogen will decrease the activity of plant metabolism that can cause chlorosis (Sastrosayono, 2005).

Sub soil is a layer of soil under the top soil layer, generally has a lower fertility rate than top soil, especially its chemical properties that are less good if used as a medium for growing oil palm seedlings (Winarna and Sutarta, 2003). This study aims to determine the appropriate dose of absorption and growth in some high yielding varieties of palm oil, knowing superior varieties of palm oil plant with efficiency to Nitrogen nutrients. Knowing the interaction between varieties and Nitrogen fertilizer on the efficiency of Nitrogen nutrient absorption. 


\section{MATERIALS AND METHOD}

This research was conducted in Palm Oil Research Centre at the District of Deli Serdang, the Province of North Sumatra. The research used Factorial Random Block Design with 2 factors. The first factor is varieties (Avros 540, PPKS 239, Simalungun, Langkat and 718PPKS). The second factor is $\mathrm{N}$ fertilizer which consists of without $\mathrm{N}$ fertilizer, $25 \%$ fertilizer recommendation, 50\% fertilizer recommendation, $75 \%$ fertilizer recommendation and $100 \%$ fertilizer recommendation.

Application of $\mathrm{N}$ fertilizer is given by way of sowing around the root of palm oil according to fertilizer recommendation treatment. The dosage of $\mathrm{N}$ fertilizer is also adjusted to the age of oil palm plantation. The observed variables were plant height $(\mathrm{cm})$, stem diameter $(\mathrm{mm})$ and number of leaves (strands). The data were analyzed statistically using F-test and then following by Duncan Multiple Range Test at $5 \%$ leve

\section{RESULTS AND DISCUSS}

\subsection{Plant height (cm)}

The result of F-test showed that the varieties were very significant effect on plant height, whereas the dosage of nitrogen fertilizer has no significant effect on plant height, while the interaction of varieties with nitrogen fertilizer shows no significant difference to plant height.

Varieties with the highest plant height were obtained in Simalungun varieties with $100 \%$ doses of recommendation of nitrogen fertilizer (V3N4), while the lowest of AVROS 540 varieties with $100 \%$ doses of recommendation of nitrogen fertilizer (V1N4) (Table 1).

Based on Table 1 it can be seen that the highest seed produced by treatment V3 (PPKSSimalungun) that is equal to $98,51 \mathrm{~cm}$ not significantly different to V5 (PPKS 718 Avros) that is $96,82 \mathrm{~cm}$. The highest interaction is in combination of V3N4 (Simalungun $+100 \%$ fertilizer recommendation) that is $109,54 \mathrm{~cm}$. This shows that the Simalungun variety with $100 \%$ recommendation $\mathrm{N}$ is the best treatment to increase the height of oil palm crop. The effect of nitrogen treatment on plant height variables in oil palm main nursery is in accordance with Shintarika's (2015) study, which shows that the application of $\mathrm{N}$ fertilizer to some extent can increase the plant height.

Table 1. Plant High Several Varieties of Palm Oil With Treatment of Nitrogen Fertilizer Dosage

\begin{tabular}{clcccccc}
\hline \multirow{2}{*}{ Days } & \multirow{2}{*}{ Plant Variety } & \multicolumn{5}{c}{ Nitrogen Fertilizer Dose $(\%)$} \\
\cline { 3 - 6 } & & $\mathrm{N} 0$ & $\mathrm{~N} 1$ & $\mathrm{~N} 2$ & $\mathrm{~N} 3$ & $\mathrm{~N} 4$ & Average \\
\hline \multirow{3}{*}{ 6 BST } & V1 (Avros 540) & 90,24 & 90,16 & 94,58 & 90,63 & 78,56 & $88,83 \mathrm{bc}$ \\
& V2 (PPKS 239) & 86,02 & 84,71 & 89,48 & 93,29 & 85,13 & $87,73 \mathrm{c}$ \\
& V3 (Simalungun) & 92,01 & 93,77 & 105,09 & 92,16 & 109,54 & $98,51 \mathrm{a}$ \\
& V4 (Langkat) & 85,30 & 83,31 & 93,63 & 83,58 & 92,56 & $87,68 \mathrm{c}$ \\
& V5 (PPKS 718 Avros) & 93,82 & 94,59 & 101,61 & 87,93 & 106,14 & $96,82 \mathrm{ab}$ \\
\hline
\end{tabular}

Note: The numbers followed by the same letter on the same row or column is not different significant according to Duncan Multiple Range Test at 5\% level

Nitrogen is one of the important elements that plants need to improve plant morphology. According to Rahhutami (2015), nitrogen is a nutrient for constituents of chlorophyll that increases the yield of photosynthates to build new cells so as to enhance the development of plant stems and increase plant height. The absorption of $\mathrm{N}$ by the plant is influenced by several internal factors, such as the physiological condition of the plant, the type of plant and the needs of the plants on certain nutrients. External or environmental factors that affect the absorption of $\mathrm{N}$ by plants, ie light, air, water and soil pH (Food Agriculture Policy Resarch Center, 1995).

\subsection{Stem diameter (g)}

Based on $\mathrm{F}$ test can be seen that the treatment of varieties have a very significant effect on stem diameter, whereas the dosage of nitrogen fertilizer and the interaction of varieties with nitrogen fertilizer has no significant effect on stem diameter.

Varieties with the highest stem diameter were obtained on Simalungun varieties with a dose of 50\% recommendation of nitrogen fertilizer (V3N2), while the lowest of PPKS 239 varieties with a dose of 25\% recommendation of nitrogen fertilizer (V2N1) (Table 2). 
Table 2. Diameter Stem of Some Palm Oil Varieties With Treatment of Nitrogen Fertilizer Dosage

\begin{tabular}{|c|c|c|c|c|c|c|c|}
\hline \multirow{2}{*}{ Days } & \multirow{2}{*}{ Plant Variety } & \multicolumn{5}{|c|}{ Nitrogen Fertilizer Dose (\%) } & \multirow{2}{*}{ Average } \\
\hline & & No & $\mathrm{N} 1$ & $\mathrm{~N} 2$ & N3 & N4 & \\
\hline \multirow{7}{*}{$6 \mathrm{BST}$} & & & & .....mm. & .................. & $\cdots$ & \\
\hline & V1 (Avros 540) & 43,32 & 45,19 & 45,47 & 43,40 & 39,24 & $43,32 b$ \\
\hline & V2 (PPKS 239) & 39,55 & 39,00 & 43,50 & 42,81 & 40,14 & $41,00 \mathrm{~b}$ \\
\hline & V3 (Simalungun) & 44,33 & 47,84 & 51,81 & 48,08 & 48,95 & $48,20 \mathrm{a}$ \\
\hline & V4 (Langkat) & 43,12 & 42,43 & 44,91 & 40,62 & 43,44 & $42,90 \mathrm{~b}$ \\
\hline & V5 (PPKS 718 Avros) & 43,90 & 41,85 & 46,69 & 42,04 & 44,30 & $43,75 \mathrm{ab}$ \\
\hline & Rataan & 42,84 & 43,26 & 46,48 & 43,39 & 43,21 & \\
\hline
\end{tabular}

Note: The numbers followed by the same letter on the same row or column is not different significant according to Duncan Multiple Range Test at 5\% level

The highest interaction was in combination of Simalungun varieties with $50 \%$ recommendation of nitrogen fertilizer that is $47.84 \mathrm{~mm}$. This shows that Simalungun varieties are varieties that respond to stem diameter increase when compared with other varieties. Each variety shows that the genetic variation factor of each variety, which has a different genetic makeup follows its parent nature, so that the height of the plant is different. This is in line with what Welsh (1981) proposes, that genetic variation is caused by genetic inheritance and environmental factors.

Simalungun variety gives more response to $50 \%$ recommendation of nitrogen fertilizer. This shows that $50 \%$ recommendation of nitrogen fertilizer is the best recommendation in increasing stem diameter. Nitrogen fertilizer recommendation as much as $50 \%$ is the optimal dose that can be absorbed by plants to meet their needs. Nitrogen when added to the soil will undergo a reaction orchanges in both physical properties or chemical properties. These changes beginoccurs when nitrogen reacts with ground water. After reacting water and fertilizerwill dissolve, some of the fertilizer will be absorbed by plants, some of which are paticatedinto a form that is not available to plants and partly lostwashed rain water (leaching) or evaporation (volatilation) (Hasibuan, 2006).

\subsection{Number of Leaves (strands)}

Based on F test can be seen that the treatment of varieties have a very significant effect on the number of leaves, whereas the dosage of nitrogen fertilizer and the interaction of varieties with nitrogen fertilizer has no significant effect on the number of leaves.

Varieties with the highest leaf number were obtained on Simalungun varieties with a dose of 50\% recommendation of nitrogen fertilizer (V3N2), while the lowest PPKS PPKS 718 Avros with 0\% recommendation of nitrogen fertilizer (V5N0) (Table 3).

Table 3. Number of Leaves of Some Varieties of Oil Palm With Treatment of Nitrogen Fertilizer Dosage

\begin{tabular}{clrccccc}
\hline \multirow{2}{*}{ Days } & \multirow{7}{*}{ Plant Variety } & \multicolumn{7}{c}{ Nitrogen Fertilizer Dose (\%) } & Average \\
\cline { 3 - 6 } & & $\mathrm{N} 0$ & $\mathrm{~N} 1$ & $\mathrm{~N} 2$ & $\mathrm{~N} 3$ & $\mathrm{~N} 4$ & \\
\hline \multirow{3}{*}{ 6 BST } & V1 (Avros 540) & 12,00 & 12,33 & 11,89 & 12,22 & 11,78 & $12,04 \mathrm{bc}$ \\
& V2 (PPKS 239) & 12,11 & 12,33 & 12,44 & 12,33 & 12,56 & $12,36 \mathrm{ab}$ \\
& V3 (Simalungun) & 12,33 & 12,89 & 13,78 & 12,78 & 12,11 & $12,78 \mathrm{a}$ \\
& V4 (Langkat) & 12,00 & 12,33 & 12,33 & 12,56 & 12,56 & $12,36 \mathrm{ab}$ \\
& V5 (PPKS 718 Avros) & 11,11 & 11,44 & 12,56 & 11,56 & 11,67 & $11,67 \mathrm{c}$ \\
\hline
\end{tabular}

Note: The numbers followed by the same letter on the same row or column is not different significant according to Duncan Multiple Range Test at 5\% level

The highest interaction is in combination of Simalungun varieties with $50 \%$ recommendation of nitrogen fertilizer that is 13,78 strands. This shows that Simalungun varieties are varieties that respond to leaf growth when compared to other varieties. This is allegedly closely related to the genetic factors of plants, which in certain phases of plants show or show different appearance with other plants according to their respective varieties. Heddy (1994) explains that specific plant growth patterns depend on the genetic and environmental variations that affect them.

The dose of $50 \%$ recommendation of nitrogen fertilizer is the best dose in increasing the number of leaves. This suggests that oil palm plants are more responsive than with other recommended doses. According to Manurung (2015), the application of nitrogen will increase the number of childrennew leaves. This corresponds to the nature of nitrogen which is a constituent elementmobile that has a high movement and movementfrom the old tissue to the 
young plant tissue so that the excess orthe influence of the nitrogen element can be easily seen in young tissuesplants such as the formation of new leaves of TBM of oil palm.

For parameter of leaf number of interaction of varieties and dose of $\mathrm{N}$ insignificant fertilizer is not real. This result is thought to be related to the nature and adaptability of a variety to its lingungan. A certain variety of growth will be maximized if the environment grows in accordance with the terms of growth. Ruchjaningsih et al. (2000) which states that the genetics of a plant have certain properties and characters that cause differences between plants with each other. Furthermore Toha (2008) adds that the potential yield of a particular variety can not be separated by the level of adaptation and stability of appearance in a growing environment.

Recommendation of nitrogen fertilizer is one of the cultivation technology to increase oil palm production. Nitrogen can increase the yield of photosynthate to build new cells in plants so nitrogen greatly affect the plant morphology such as plant height, plant diameter and number of leaflets (Rahhutami, 2015).

\section{CONCLUSIONS}

Factors of oil palm varieties have a very significant effect on the height of the plant, stem diameter and number of leaves.Giving nitrogen fertilizer has no significant effect on plant height, stem diameter and number of leaves. Simalungun variety is the best variety and its combination with giving $100 \%$ recommendation $\mathrm{N}$ is the best treatment in increasing the height of oil palm crop. While giving $50 \%$ recommendation $\mathrm{N}$ is the best treatment in increasing the diameter and number of oil palm leaves.

\section{REFERENCES}

Chaturvedi I. 2005. Effect of nitrogen fertilizer on growth, yield and quality of hybrid rice (Oryza sativa L.). J Eur Agric 6 (4): 611-618.

[Deptan] Departemen Pertanian. 2015. Tabel Luas Areal Produksi dan Produktivitas Perkebunan di Indonesia Tahun 2011-2015. Diaksesdari http://www.deptan.go.id// padatanggal 7 Agustus 2016

Duan Y. H., Zhang Y. L., Ye L. Y., Fan X. R., Xu G. H., Shen Q. R. 2007. Responses of rice cultivars with different nitrogen use efficiency to partial nitrate nutrition. Ann Bot 99: 1153-1160.

[FAPRC] Food Agriculture Policy Research Center. 1995. Science of the Rice Plant, volume 2, Physiology. Tokyo: Nobunkyo.

Sastrosayono, 2005. Nilai Agronomi Fosfat Alam Untuk Tanaman Kelapa Sawit Calopogonium Caerulum .Menara Perkebunan. Pekanbaru.

Schulze ED, MM Caldwell. 1995. Ecophysiology of Photosynthesis. New York: Springer-Verlag.

Siallagan I. 2014. Optimasi pupuk organic dan NPK majemuk pada tanaman kelapa sawit (Elaeis Guineensis Jacq.) belummenghasilkanberumursatutahun. [tesis] Bogor (ID). Institut Pertanian Bogor.

Wachjar, A., A. Darwis., dan Sudradjat. 2014. Optimasi Dosis Pupuk Nitrogen dan Fosfor pada Bibit Kelapa Sawit (ElaeisguineensisJacq.) di Pembibitan Utama. JurnalAgronomi Indonesia 42 (3): 222 - 227.

Zheng YM, YF Ding, QS Wang, GH Li, H Wu, Q Yuan, HZ Wang, SH Wang. 2007. Effect of nitrogen applied before transplanting on nutrient use effeciency in rice. Agric ScChn 6 (7):84

Welsh, J. R. 1981. Dasar-Dasar Genetika dan Pemuliaan Tanaman. Diterjemahkan oleh Johanis P. Mogeadari Fundamental of Plant Genetic and Breeding. Erlangga. Jakarta.

Hasibuan B.E. 2006. Pupuk dan Pemupukan. Fakultas pertanian. Universitas Sumatra Utara. Medan.

Manurung A.N.H. 2015. Optimization Rate of Organic and NPK Compound Fertilizers on Second Year Immature Oil Palm. [tesis] Bogor (ID): Institut Pertanian Bogor. 